\title{
OSTEOMETRIC GENDER DETERMINATION FROM ADULT FEMORAL DISTAL END IN MINIA GOVERNORATE, EGYPT
}

\author{
Samah Mohammed Mahmoud Abozaid*, Eman Ismail Hasan** \\ Anatomy department*, Forensic medicine and Clinical Toxicology department**, Faculty of \\ Medicine- Minia University
}

\begin{abstract}
Determination of sex from human skeletal remains plays an important role in establishing identity. Femur is an important bone used for gender determination. Objective: this study aimed to derive equations for sex prediction based on measurements of distal fragments of the femur for Egyptian population. Methodology: the study was done on 96 dry completely ossified femurs of both sexes; 51 male (21 right, 30 left), and 45 female ( 24 right, 21 left). Five dimensions of the distal femoral end were assessed by the help of Vernier caliper then statistically analyzed; epicondylar breadth, bicondylar breadth, medial condylar depth, lateral condylar depth, and the distance from intercondylar fossa to the medial condyle. Results: the male mean values were found to be greater than that of females, confirming the sexual dimorphism of these parameters. The most accurate univariate discriminant variable for each side was the epicondylar breadth. Although the two condylar depths had high accuracy rate in the right side, they were the least discriminant variables for sex determination in the left side. The best accuracy, 93.3\%, $94.1 \%$ for right and left side respectively, was obtained from multiple discriminant analysis of the five studied dimensions. Conclusion: this research highlighted the importance of distal femur end in assessment of sex from human skeletal remains, especially in cases of incomplete femur bone.
\end{abstract}

Key words: femur, sex, condylar breadths, condylar depths

\section{INTRODUCTION}

Skeletal components of the human body play an important role in identification because of their resistance to heat and degradative process, but the soft tissues cannot contribute much in the identification process because they don't have that resistance (Khanal et al., 2017a). The three most essential determinations; Age, sex and racial affinity must be identified when dealing with skeletal remains. It is impossible to identify an individual without them (Pandey and Gaikwad, 2016).

Sex is one of the most important and reliable determinations made from skeletal material if the essential parts of the skeleton are present within good condition (Singh, 2017). Not only did the completeness of the remains affect the accuracy of sex determination, but also the degree of sexual dimorphism of skeleton (Gomaa et al., 2007).

The long bones have been used in sex discrimination because of the ease in defining measurements and best preservation, especially the femur as it is the longest bone (Monisha and Karpagam, 2016). The femur was more reliable than the tibia in sex discrimination (Alunni-Perret et al., 2008). The accuracy for sex discrimination is enhanced by the 
availability of multiple femoral measurable variables; therefore its ranking is third behind the pelvis and cranium. (Doshi and Bhaskar, 2017). Sexual dimorphism of the femur is encourged by the difference in the relative axial skeleton weight of males and females (Purkait, 2005).

Fragments of long bones (because of injury, mutilation, destruction, or post mortem biting by wild animals) are often presented as the only available source to establish identity (Mukhopadhyay et al., 2010). Sex affected the extremities of the long bone which was the site for a number of muscles insertions as they are subjected to more pull than the points of muscles origin (Lee et al., 2014).

Recently, studies about sex identification have been done on Egyptian population using different identification tools, and different bones rather than the distal femoral end. The considerable results form a useful profile reference for sex identification of Egyptians (Mostafa et al., 2012).

\section{AIM OF WORK}

The aim of this study was sex determination for the Egyptian populationfrom femoral distal end measurements, by applying discriminant function analysis.

\section{MATERIALS \& METHODS}

This study was conducted in the anatomy and forensic medicine departments, faculty of medicine, Minia University. The cadaveric study was conducted on 96 dry completely ossified femurs of both sexes; 51 male (21 right, 30 left), and 45 female (24 right, 21 left). The age for both sexes at death ranged between 21 and 60 years. Only bones free of fractures, osteoarthritis, deformity and any other apparent pathological changes were selected. Present study was done on dry human bones, so ethical issues were not arisen.

Five dimensions of the distal femoral end were chosen according to Khanal et al. (2017a), and were measured by using Vernier caliper (to nearest $\mathrm{mm}$ ):

1. Epicondylar breadth (EB): The linear distance between the medial and the lateral epicondyles of the femur (fig. 1).

2- Bicondylar breadth (BB): The maximum distance across the femoral condyles in the transverse plane (fig. 2).

.3- Medial condyle depth (MCD): The linear distance between the most anterior and the most posterior points on the medial condyle (fig. 3 ).

4- Lateral condyle depth (LCD): The linear distance of the lateral condyle measured in an anteroposterior direction (fig. 4).

5- Intercondylar fossa medial condyle length (IML): Distance from the proximal point of the intercondylar fossa to the most distal point of the medial condyle (fig. 5).

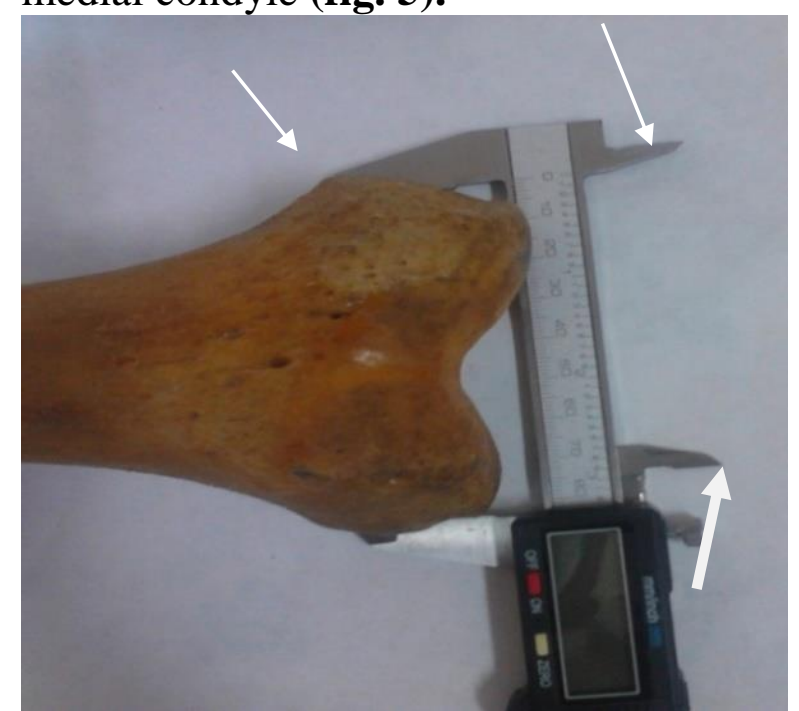

Figure (1): showing measurement of epicondylar breadth (EB): distance between the medial epicondyle (thick arrow) and the lateral epicondyle (thin arrow) 


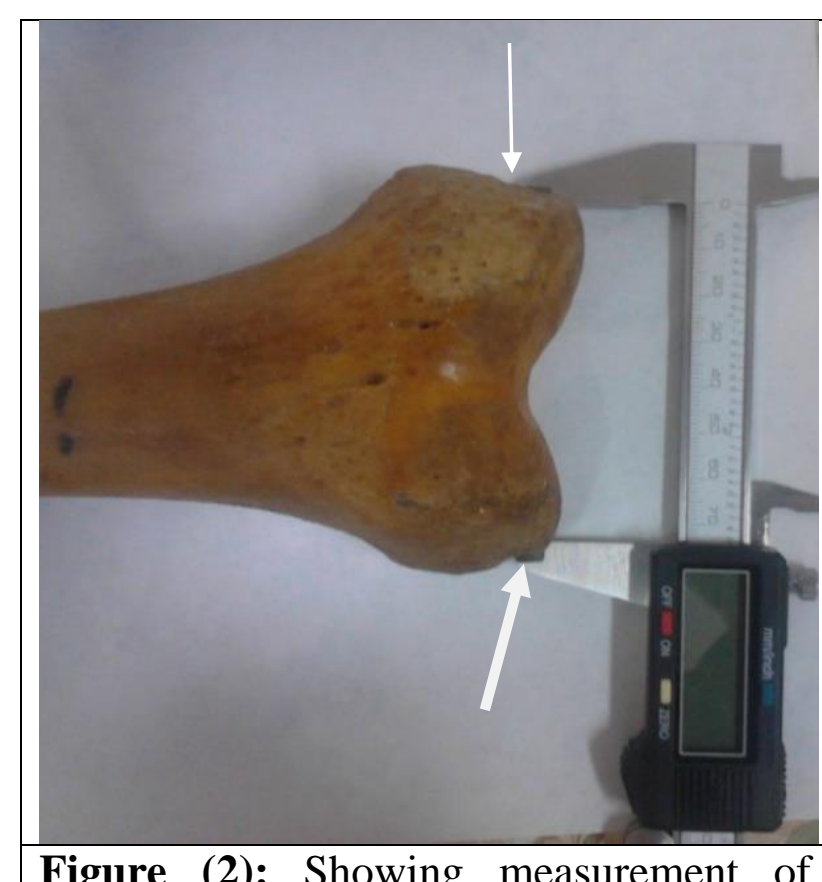

Figure (2): Showing measurement of bicondylar breadth (BB): distance across the medial condyle (thick arrow) and the lateral condyle (thin arrow)

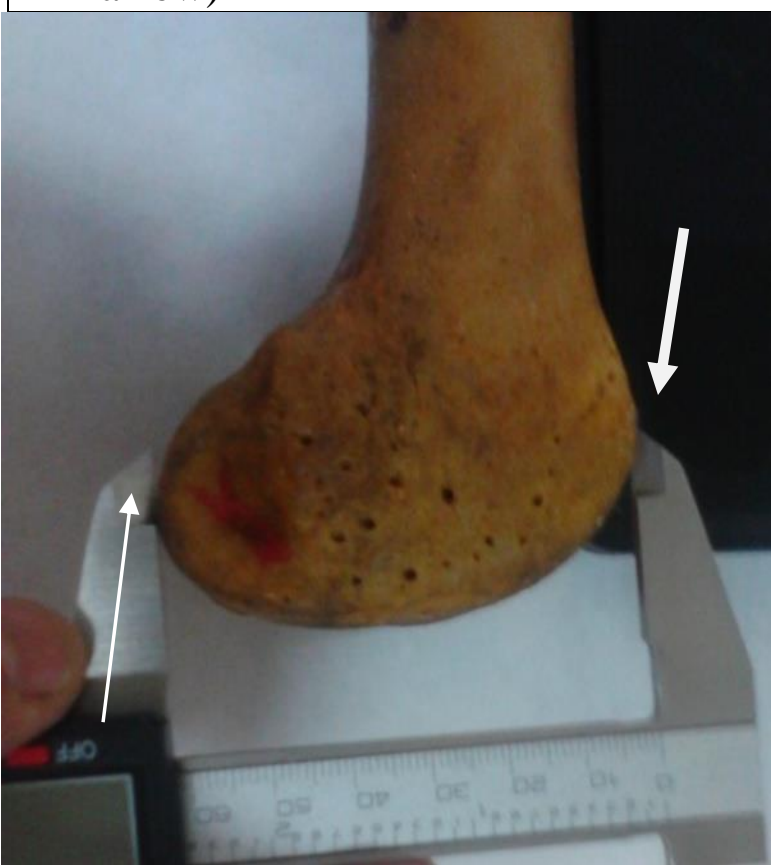

Figure (4): Showing lateral condyle depth (LCD): distance of the lateral condyle measured in an antero (thick arrow)posterior (thin arrow) direction

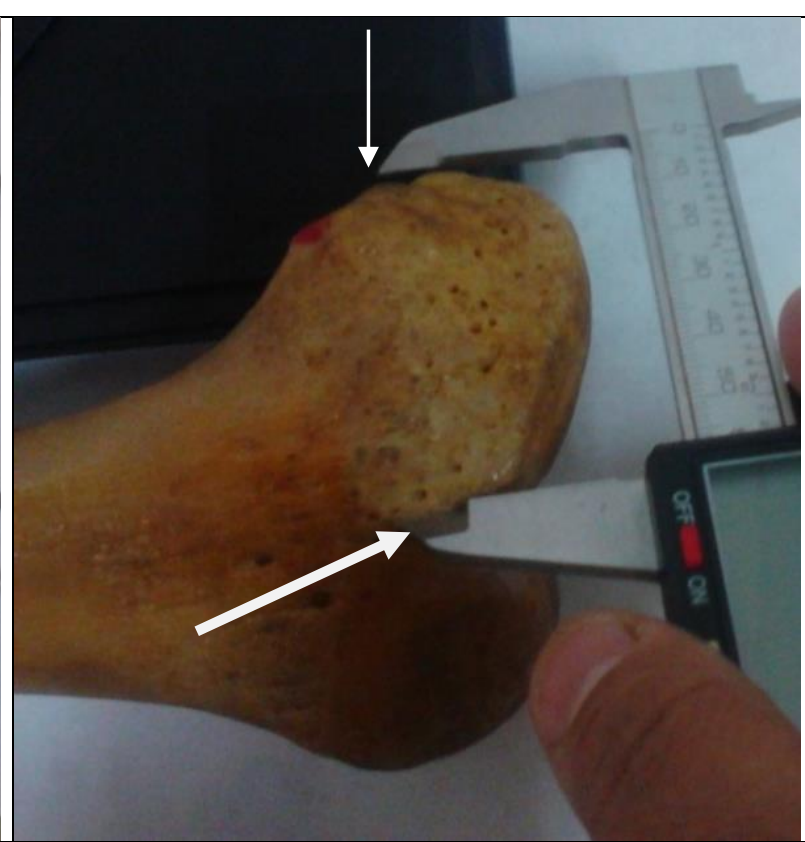

Figure (3): Showing medial condyle depth (MCD): distance from the most anterior point (thick arrow) to the most posterior point (thin arrow) of the medial condyle

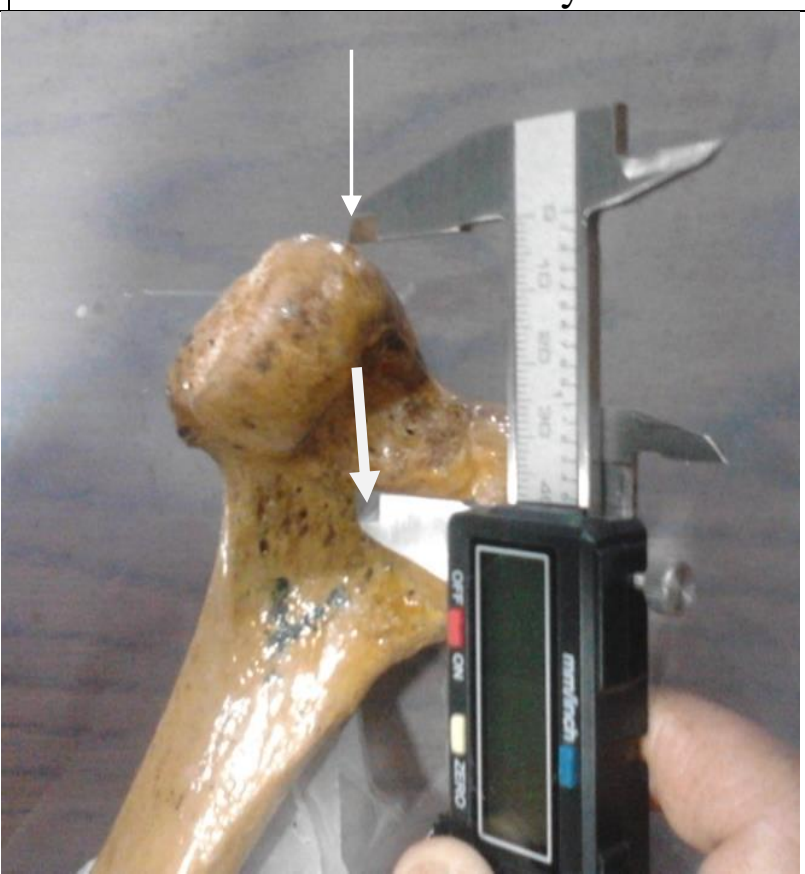

Figure (5): Showing intercondylar fossa medial condyle length (IML): distance from intercondylar fossa (thick arrow) to the medial condyle (thin arrow) 


\section{Statistical Analysis}

The data were analyzed using SPSS statistical package version 20. A level of significance $(\mathrm{p}<0.05)$ was adopted for all the performed tests. Mean and standard deviations were obtained for all measurements of each side of each sex. Student-t test was done to establish the presence of significant sexual differences.

For sex prediction, discriminant function analysis was made: single, multiple, and stepwise. Discriminant function (df) is the result of addition of the constant to the product of the variable and its coefficient i.e. $\mathrm{df}=($ variable $\times$ coefficient $)+$ constant. When $\mathrm{df}$ is above the sectioning point, the individual was predicted as male (and vice versa). Stepwise discriminant function was performed to determine the most significant variables contributing to gender discrimination.

Roc (receiver operating characteristic) curve analysis was done to obtain the optimal cut off value, sensitivity, and specificity of the most significant parameters in sex prediction. If the measured value was equal to or higher than the cut-off value, male gender would be highly probable (and vice versa).

\section{RESULTS}

Statistical analysis for the measured dimensions of each side showed that all the five variables are greater in male than those of females significantly $(\mathrm{p}<$ 0.001) except left IML whose difference was insignificant (Table 1).

The efficiency of sex determination for each of the 5 femoral dimensions was done by using simple (univariate) discriminant analysis. Standardized discriminant function coefficients indicated the relative contribution of each variable to sex discrimination.
While the greatest contribution was made by the EB or BB in the left side, it was made by EB or MCD or LCD in the right side. Left MCD or left LCD was the least predictable parameter for sex prediction (accuracy percentage 64.7\%) (Table 2).

By multiple discriminant analysis, combination of the significant parameters was done i.e. $\mathrm{df}=(\mathrm{EB} \times$ coefficient $)+(\mathrm{BB} \times \quad$ coefficient $)+$ $(\mathrm{MCD} \times \quad$ coefficient $)+\quad(\mathrm{LCD} \times$ coefficient $)+($ IML $\times$ coefficient $)+$ constant:

Right $\quad d f=(E B \times 0.549)+(B B \times-$
$0.379)+($ MCD $\times 0.270)+(L C D \times-$
$0.229)+(I M L \times 0.089)+(-21.616)$

Left $\mathrm{df}=(\mathrm{EB} \times \mathbf{0 . 4 0 4})+(\mathrm{BB} \times-$ $0.043)+($ MCD $\times-0.2)+($ LCD $\times$ 0.297) + (-34.646)

If the df was greater than the sectioning point, it means male (and vice versa). Percentage of accuracy by multiple discriminant analysis was $85.7 \%$ and $90 \%$ for right and left side respectively in males, and $100 \%$ for both sides in females (Table 3).

Stepwise analysis was run on 5 measurements from the femur. When all 5 variables were entered for the Femur, selected variables included right LCD or left EB showed largest metric discrimination between the sexes (Table 4). Stepwise analysis of the right femurs showed that $\mathbf{d f}=\mathbf{- 1 8 . 4 9 1 +}$ $0.32 \times$ right $\mathbf{L C D}$, and so if the df $>0.078$, the predicted sex was male and vice versa. For the left femur, male person was predicted if $\mathrm{df}$ was more than $-0.24(\mathbf{d f}=\mathbf{- 2 4 . 9 9}+\mathbf{0 . 3 2} \times$ left EB).

ROC-curve analysis showed that EB proved to be the most distinctive measurements for sexual dimorphism with the highest accuracy $(93.33 \%$, $94.12 \%$ ) when the cutoff value used for males $>76$ or $>77$ for right or left side 
respectively. The distances $\mathrm{EB}, \mathrm{BB}$ were the most sensitive variables for identification, while the distance MCD was the most specific variable for identification (100\%) (Table 5, Fig. 6, 7)

Sex prediction from the right femur revealed that if the cutoff value was $\geq$ $(66,56,55,35)$ for $(\mathrm{BB}, \mathrm{MCD}, \mathrm{LCD}$, IML respectively), the sex was male and vice versa. Cutoff values of the left femur were 67 for $\mathrm{BB}$, and 59 for MCD or LCD (Table 5).

Table (1): Student t-testof the 5 femoral dimensions for both sexes

\begin{tabular}{|c|c|c|c|c|c|c|}
\hline \multirow{2}{*}{$\begin{array}{c}\text { Variable } \\
(\mathrm{mm})\end{array}$} & \multicolumn{2}{|c|}{ Male(M) } & \multicolumn{2}{c|}{ Female(F) } & \multicolumn{2}{c|}{ P value } \\
\cline { 2 - 7 }$(\mathbf{n = 2 1})$ & $\begin{array}{c}\text { Left } \\
(\mathbf{n = 3 0})\end{array}$ & $\begin{array}{c}\text { Right } \\
(\mathbf{n = 2 4})\end{array}$ & $\begin{array}{c}\text { Left } \\
(\mathbf{n = 2 1})\end{array}$ & Right & Left \\
\hline $\begin{array}{c}\text { EB } \\
\mathrm{M} \pm \mathrm{SD}\end{array}$ & $83.4 \pm 4.7$ & $81.5 \pm 3.6$ & $74.1 \pm 3.5$ & $73.1 \pm 2.2$ & $<\mathbf{0 . 0 0 1 *}$ & $<\mathbf{0 . 0 0 1 *}$ \\
\hline $\begin{array}{c}\text { BB } \\
\text { M } \pm \text { SD }\end{array}$ & $74.7 \pm 4.7$ & $73.1 \pm 4.2$ & $67.3 \pm 4.3$ & $65.4 \pm 2.9$ & $<\mathbf{0 . 0 0 1 *}$ & $<\mathbf{0 . 0 0 1 *}$ \\
\hline $\begin{array}{c}\text { MCD } \\
\text { M } \pm \text { SD }\end{array}$ & $60.6 \pm 3.7$ & $60.9 \pm 4.8$ & $52.8 \pm 3$ & $55.6 \pm 3.9$ & $<\mathbf{0 . 0 0 1 *}$ & $<\mathbf{0 . 0 0 1 *}$ \\
\hline $\begin{array}{c}\text { LCD } \\
\text { M } \pm \text { SD }\end{array}$ & $61.9 \pm 3.5$ & $61.3 \pm 3$ & $54.1 \pm 2.7$ & $58.4 \pm 2.3$ & $<0.001 *$ & $<\mathbf{0 . 0 0 1 *}$ \\
\hline $\begin{array}{c}\text { IML M } \pm \\
\text { SD }\end{array}$ & $41.3 \pm 6.3$ & $37 \pm 3.7$ & $34.4 \pm 2.4$ & $35.1 \pm 4.6$ & $<\mathbf{0 . 0 0 1 *}$ & 0.115 \\
\hline
\end{tabular}

$\mathrm{EB}=$ epicondylar breadth, BB=Bicondylar breadth, MCD=Medial condyle depth, LCD=Lateral condyle depth, IML=Intercondylar fossa medial condyle length $\mathrm{M}=$ mean, $\mathrm{SD}=$ standard deviation, $*=$ significance $(\mathrm{p}<0.05)$

Table (2): Simple discriminant functional analysis for sex prediction

\begin{tabular}{|c|c|c|c|c|c|c|c|}
\hline \multirow{4}{*}{ Side } & \multirow{2}{*}{ Variable } & \multirow{2}{*}{ Constant } & \multirow{2}{*}{ Coefficient } & \multirow{2}{*}{$\begin{array}{c}\text { Sectioning } \\
\text { point }\end{array}$} & \multicolumn{3}{|c|}{$\begin{array}{c}\text { Cross validated } \\
\text { Accuracy (\%) }\end{array}$} \\
\cline { 5 - 8 } & & & & M & F & total \\
\hline \multirow{4}{*}{ Right } & EB & -19.152 & 0.244 & 0.076 & 85.7 & 87.5 & 86.7 \\
\cline { 5 - 8 } & BB & -15.7 & 0.222 & 0.056 & 85.7 & 75 & 80 \\
\cline { 2 - 8 } & MCD & -16.817 & 0.298 & 0.078 & 71.4 & 100 & 86.7 \\
\cline { 2 - 8 } & LCD & -18.491 & 0.32 & 0.078 & 85.7 & 87.5 & 86.7 \\
\cline { 2 - 8 } & IML & -8.094 & 0.215 & 0.045 & 57.1 & 100 & 80 \\
\hline \multirow{4}{*}{ Left } & EB & -24.99 & 0.32 & -0.24 & 90 & 85.7 & 88.2 \\
\cline { 2 - 8 } & BB & -18.945 & 0.271 & -0.18 & 90 & 85.7 & 88.2 \\
\cline { 2 - 8 } & MCD & -13.209 & 0.225 & -0.11 & 70 & 57.1 & $\mathbf{6 4 . 7} \downarrow$ \\
\cline { 2 - 8 } & LCD & -21.835 & 0.363 & -0.092 & 80 & 42.9 & $\mathbf{6 4 . 7} \downarrow$ \\
\hline
\end{tabular}

$\mathrm{M}=$ male, $\mathrm{f}=$ female, $\mathrm{EB}=$ =picondylar breadth, $\mathrm{BB}=$ Bicondylar breadth, $\mathrm{MCD}=$ Medial condyle depth, $\mathrm{LCD}=$ Lateral condyle depth, IML=Intercondylar fossa medial condyle length 
Table (3): Multiple discriminant functional analysis for sex prediction

\begin{tabular}{|c|c|c|c|c|c|c|c|c|c|}
\hline \multirow[t]{2}{*}{$\mathbf{S}$} & \multirow[t]{2}{*}{ V } & \multirow{2}{*}{$\begin{array}{l}\text { Wilk's } \\
\text { lambda }\end{array}$} & \multirow{2}{*}{$P$ value } & \multirow{2}{*}{ Constant } & \multirow{2}{*}{ Coefficient } & \multirow{2}{*}{$\begin{array}{l}\text { Sectioning } \\
\text { point }\end{array}$} & \multicolumn{3}{|c|}{$\begin{array}{c}\text { Cross validated } \\
\text { Accuracy (\%) }\end{array}$} \\
\hline & & & & & & & M & $\mathbf{F}$ & total \\
\hline \multirow{5}{*}{$\mathbf{R}$} & EB & \multirow{5}{*}{0.269} & \multirow{5}{*}{$<0.001^{*}$} & \multirow{5}{*}{-21.616} & 0.549 & \multirow{5}{*}{0.108} & \multirow{5}{*}{85.7} & \multirow{5}{*}{100} & \multirow{5}{*}{93.3} \\
\hline & BB & & & & -0.379 & & & & \\
\hline & MCD & & & & 0.270 & & & & \\
\hline & LCD & & & & -0.229 & & & & \\
\hline & IML & & & & 0.089 & & & & \\
\hline \multirow{4}{*}{$\mathbf{L}$} & EB & \multirow{4}{*}{0.331} & \multirow{4}{*}{$<0.001 *$} & \multirow{4}{*}{-34.646} & 0.404 & \multirow{4}{*}{-0.25} & \multirow{4}{*}{90} & \multirow{4}{*}{100} & \multirow{4}{*}{94.1} \\
\hline & BB & & & & -0.043 & & & & \\
\hline & MCD & & & & -0.2 & & & & \\
\hline & LCD & & & & 0.297 & & & & \\
\hline
\end{tabular}

S=side, $V=$ variable, $R=$ right, l=left,M=male, $F=$ female,

$\mathrm{EB}=$ =epicondylar breadth, $\mathrm{BB}=\mathrm{Bicondylar}$ breadth, $\mathrm{MCD}=$ Medial condyle depth, LCD=Lateral condyle depth, IML=Intercondylar fossa medial condyle length $*$ =significance $(\mathbf{p}<\mathbf{0 . 0 5})$

Table 4: Multiple stepwise discriminant functional analysis for sex prediction

\begin{tabular}{|c|c|c|c|c|c|c|c|c|}
\hline & Wilk's & P value & Constant & Coefficient & \multirow{2}{*}{$\begin{array}{c}\text { Sectioning } \\
\text { point }\end{array}$} & \multicolumn{3}{|c|}{$\begin{array}{c}\text { Cross validated } \\
\text { Accuracy (\%) }\end{array}$} \\
\cline { 6 - 10 } & lambda & & & & & M & F & total \\
\hline $\begin{array}{c}\text { Right: } \\
\text { LCD }\end{array}$ & 0.385 & $<0.001 *$ & -18.491 & 0.32 & 0.078 & 85.7 & 87.5 & 86.7 \\
\hline $\begin{array}{c}\text { Left: } \\
\text { EB }\end{array}$ & 0.357 & $<0.001 *$ & -24.99 & 0.32 & -0.24 & 90 & 85.7 & 88.2 \\
\hline
\end{tabular}

$\mathrm{V}=$ variable, $\mathrm{M}=$ male, $\mathrm{F}=$ female,

EB=epicondylar breadth, $L C D=$ Lateral condyle depth,

$*$ =significance $(\mathbf{p}<\mathbf{0 . 0 5})$

Table (5): ROC curve analysis of the femur for prediction of male sex

\begin{tabular}{|c|c|c|c|c|c|c|c|}
\hline \multirow{3}{*}{ Side } & Variable & $\begin{array}{c}\text { Optimal } \\
\text { Cutoff } \\
\text { point }\end{array}$ & AUC & P value & Sens & Spec & Accuracy \\
\hline \multirow{4}{*}{ R } & EB & $\geq 76$ & 0.946 & $<0.001^{*}$ & 100 & 87.5 & 93.33 \\
\cline { 2 - 8 } & BB & $\geq 66$ & 0.857 & $<0.001^{*}$ & 100 & 62.5 & 80 \\
\cline { 2 - 8 } & MCD & $\geq 56$ & 0.964 & $<0.001^{*}$ & 71.43 & 100 & 86.7 \\
\cline { 2 - 8 } & LCD & $\geq 55$ & 0.964 & $<0.001^{*}$ & 100 & 75 & 86.7 \\
\cline { 2 - 8 } & IML & $\geq 35$ & 0.830 & $<0.001^{*}$ & 85.71 & 75 & 80 \\
\hline \multirow{4}{*}{ L } & EB & $\geq 77$ & 0.986 & $<0.001^{*}$ & 90 & 100 & 94.12 \\
\cline { 2 - 8 } & BB & $\geq 67$ & 0.950 & $<0.001^{*}$ & 90 & 85.71 & 88.2 \\
\cline { 2 - 8 } & MCD & $\geq 59$ & 0.786 & $<0.001^{*}$ & 60 & 85.71 & 70.6 \\
\cline { 2 - 8 } & LCD & $\geq 59$ & 0.757 & $<0.001^{*}$ & 80 & 71.43 & 76.5 \\
\hline
\end{tabular}

R=right, L=left, EB=epicondylar breadth, BB=Bicondylar breadth, MCD=Medial condyle depth, $\mathrm{LCD}=$ Lateral condyle depth, IML=Intercondylar fossa medial condyle length, sens=Sensitivity, spec=Specificity, ${ }^{*}=$ significance $(p<0.05)$ 


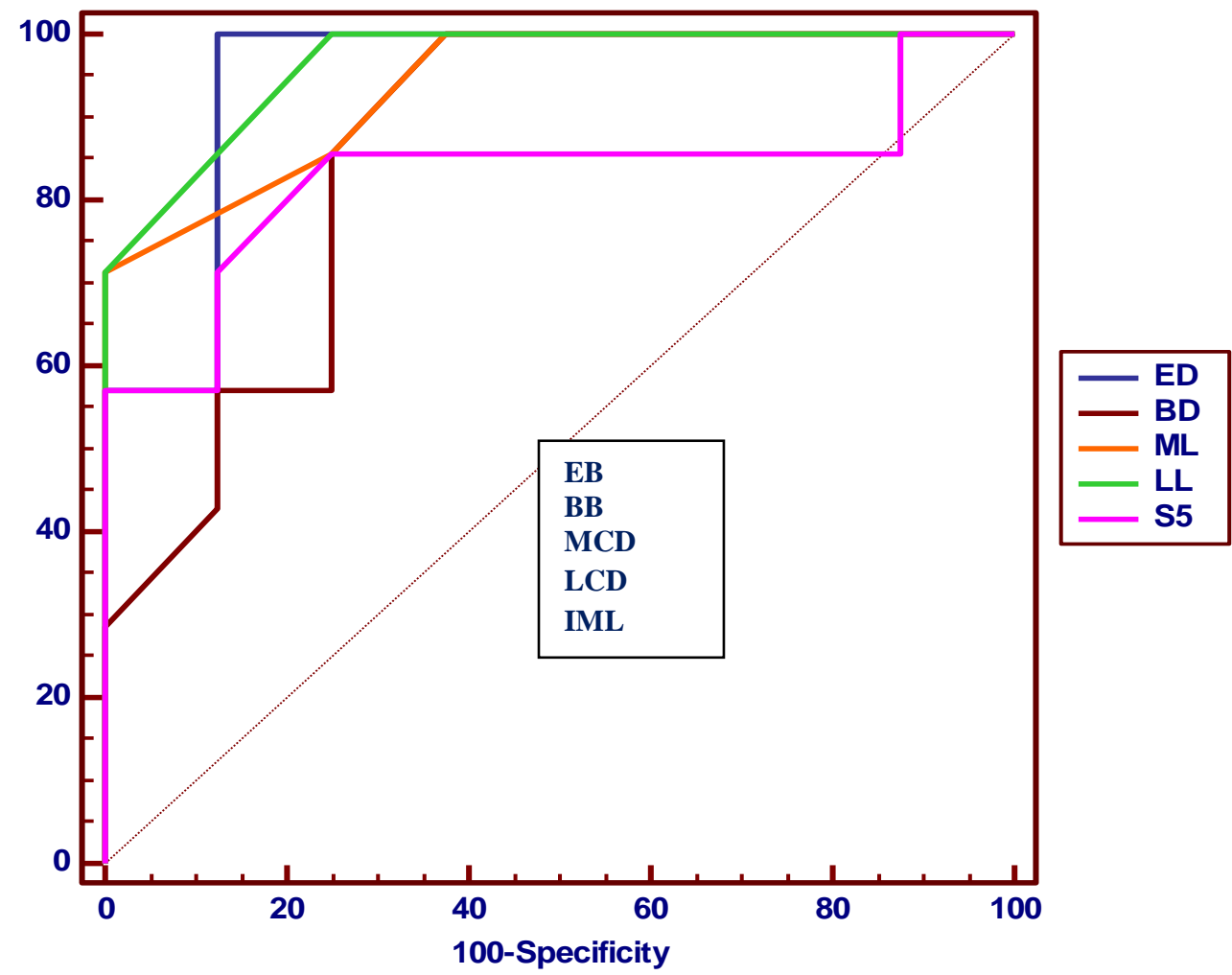

Figure (6): ROC curve of the right-sided femur

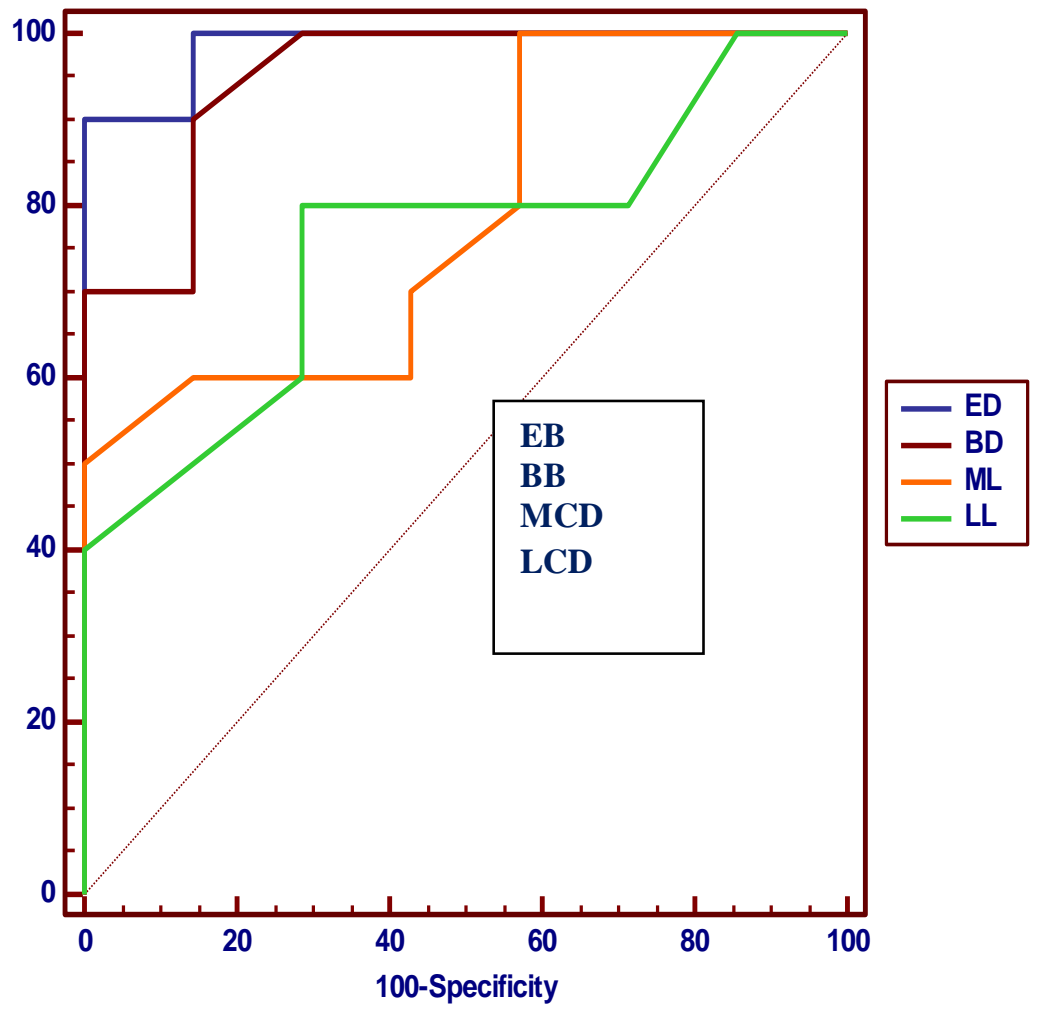

Figure (7): ROC curve of the left-sided femur 


\section{DISCUSSION}

The secular trends in Americans were more pronounced in lower limbs than the upper limbs. Also,they insisted that the femur is a highly useful bone for sex determination (Kranioti et al., 2009). As the medial and lateral femoral epicondyleshave no articular cartilage, and so some diseases such as osteoarthritis does not affect them(Alunni-Perret et al., 2008). The forensic expert commonly confronted with poorly preserved or fragmented bones (Soni et al., 2010). So, this research was done for sex discrimination of individual from femoral distal end measurements, named EB, BB, MCD, LCD, and IML.
Table 6 showed mean values of the measured dimensions in some populations, which collected from researches done in the current century. There were variability in osteometric dimensions between different populations, even when they were located in the same continent; South Africans or Ghanaians had different values from Egyptians. This ensures that population specific studies in this aspect are obligatory for sex determination (Soni et al., 2010), and then standards specific to each population would be used in determination of sex from various skeletal parts (Doshi and Bhaskar, 2017).

Table 6: Mean values of the five studied dimensions in some populations

\begin{tabular}{|c|c|c|c|c|c|c|c|c|c|c|c|}
\hline \multirow{2}{*}{ Country } & \multirow{2}{*}{ side } & \multicolumn{2}{|c|}{ EB } & \multicolumn{2}{|c|}{ BB } & \multicolumn{2}{|c|}{ MCD } & \multicolumn{2}{|c|}{ LCD } & \multicolumn{2}{|c|}{ IML } \\
\hline & & $\mathbf{M}$ & F & $\mathbf{M}$ & $\mathbf{F}$ & $\mathbf{M}$ & $\mathbf{F}$ & M & $\mathbf{F}$ & $\mathbf{M}$ & $\mathbf{F}$ \\
\hline $\begin{array}{l}\text { South Africa } \\
\text { (Bidmos, } \\
\text { 2008) }\end{array}$ & $\mathrm{L}$ & 74.93 & 66.6 & 78.72 & 69.96 & 64.55 & 57.86 & 64.73 & 59.86 & & \\
\hline $\begin{array}{c}\text { France } \\
\text { (Alunni-Perret } \\
\text { et al., 2008) }\end{array}$ & $\mathrm{L}$ & 84.3 & 74.8 & & & & & & & & \\
\hline $\begin{array}{l}\text { Korea (Lee et } \\
\text { al., 2014) }\end{array}$ & $\mathrm{R}$ & 83.1 & 74 & 75.5 & 66.2 & & & & & & \\
\hline \multirow[b]{2}{*}{ India } & & 75.1 & 67.1 & & & & & & & \multirow{2}{*}{\multicolumn{2}{|c|}{$\begin{array}{c}\text { Rt } 3.09 \\
\text { Lt } 2.77 \\
\text { (Solan and } \\
\text { Kulkarni, } \\
\text { 2013) }\end{array}$}} \\
\hline & & \multicolumn{2}{|c|}{$\begin{array}{c}\text { (Monisha and } \\
\text { Karpagam, } \\
\text { 2016) } \\
\end{array}$} & & & & & & & & \\
\hline $\begin{array}{c}\text { Ghana(Abledu } \\
\text { et al., 2016) }\end{array}$ & & \multicolumn{2}{|c|}{77.3} & \multicolumn{2}{|c|}{70.4} & & & & & & \\
\hline \multirow{2}{*}{$\begin{array}{c}\text { Nepal } \\
\text { (Khanal et al., } \\
\text { 2017b) }\end{array}$} & $\mathrm{R}$ & \multicolumn{2}{|c|}{74.7} & & & \multicolumn{2}{|c|}{58.6} & \multicolumn{2}{|c|}{54.9} & \multicolumn{2}{|c|}{31.7} \\
\hline & $\mathrm{L}$ & \multicolumn{2}{|c|}{75.1} & & & \multicolumn{2}{|c|}{56.2} & \multicolumn{2}{|c|}{57.1} & \multicolumn{2}{|c|}{31.8} \\
\hline \multirow{2}{*}{$\begin{array}{c}\text { Egypt } \\
\text { (Present } \\
\text { study, 2018) }\end{array}$} & $\mathrm{R}$ & 83.4 & 74.1 & 74.7 & 67.3 & 60.6 & 52.8 & 61.9 & 54.1 & 41.3 & 34.4 \\
\hline & $\mathrm{L}$ & 81.5 & 73.1 & 73.1 & 65.4 & 60.9 & 55.6 & 61.3 & 58.4 & 37 & 35.1 \\
\hline
\end{tabular}

EB=epicondylar breadth, $\mathrm{BB}=$ Bicondylar breadth, MCD=Medial condyle depth, LCD=Lateral condyle depth,IML=Intercondylar fossa medial condyle length, $\mathrm{R}=$ right, $\mathrm{L}=$ left, $\mathrm{M}=$ male, $\mathrm{F}=$ female 
The differences which were found in mean values of the measured femoral lower end distances when compared to other studies could be explained by two factors; demographic factors such as age and race, and environmental factors affecting bone growth as nutrition, physical development, and genetic variation. The different anatomical reference points which were chosen in the bone measurement might participate in producing these differences (Solan \& Kulkarni, 2013).

The present study results revealed that all measured distances in right or left side except one distance (IML of the left side) were significantly different between the sexes at the level of $p<0.001$, and this significant difference was taken into consideration when dealing with subsequent statistics. These results were in coincidence with Bidmos, (2008). Measurements of the distal end of the femur of the Indigenous South African population group have been shown to be sexually dimorphic in a previous study by Asala et al.(2004).

The difference between male and female femurs could not be explained based on exact evidence, but they might be due to different growth patterns between them that could underlie the different growth forms in various femoral segmental levels (Melamed et al., 2013). The male femur beard more stress than female femur because of the male heavier body weights, and so the different femoral measurements between the two genders (Khanal et al., 2017).

Singh, (2017) suggested that the discriminant function analysis was the best choice for achievement the accuracy of the resulted sexual differences. Doshi and Bhaskar, (2017), reported that the accuracy for sex prediction was enhanced by the availability of multiple femoral measurements.

In this Egyptian study, results of univariate discriminant function mentioned that the Egyptian femur was a good skeletal component for determining sex, with an accuracy of 64.7-88.2\%. Although EB achieved the highest accuracy rate in each side in relation to other measured dimensions (86.7, 88.2 in $\mathrm{Rt}$ and $\mathrm{Lt}$ sides respectively), there was no recommendation for using $\mathrm{EB}$ alone for sex determination as the accuracy rate by multiple discriminant function in this study raised to $(93.3,94.1$ in $\mathrm{Rt}$ and Lt sides respectively).

Ashmawy et al., (2004) carried out a sex determination study on Egyptian right femur using six osteometric variables, and concluded that the distal breadth (EB) was the most reliable variable for sex prediction, and that conclusion was in agreement with the current research.

The only length-related variable in the current research; IML revealed the least accuracy in the right side, and moreover insignificant change in the left side. This study supported the findings of earlier studies indicating that breadth and circumference measurements of long bones were often more sexually dimorphic than lengthrelated variables in South Africans (Asala et al., (2004), Germans (Mall et al., 2000), and Indians (Purkait \&Chandra, 2004). This fact is beneficial because bones are usually found in a fragmentary condition (Lee et al., 2014).

\section{CONCLUSION}

1- The femur was used to determine sex, and the results demonstrated the existence of a strong 
sexual dimorphism in the studied Egyptian sample.

2- The best accuracy of $93.3 \%$, $94.1 \%$ for right and left side respectively was generated upon multiple discriminant analysis of the five dimensions.

3- If the studied parameters were not available except one, cut-off value of this one would be the most accurate reference for sex determination.

The femoral distal end measurements done in our study and the obtained results are recommended to be used in the forensic practice, for sex discrimination of unidentified human skeletal remains.

\section{LIMITATION OF THE STUDY}

This study had limitation of having small sample size, thus a larger sample is required to yield more authoritative results for Egyptian population. Secondly, demographic characteristics which may affect growth and development of various body parts were unknown, such as age, nutritional status, occupation, etc.

\section{REFERENCES}

Abledu, J.K.; Offei, E.B. and Osabutey, C.K. (2016):

Reconstruction of femoral length from fragmentary femora. Anat Cell Biol, 49: 206-209

Alunni-Perret, V.; Staccini, P. and Quatrehomme, G. (2008): Sex determination from the distal part of the femur in a French contemporary population. Forensic Sci. Int., 175 (2-3): 113-117.

Asala, S.A.;Bidmos, M.A. and Dayal, M.R. (2004): Discriminant functionsexing of fragmentary femur of South African blacks. Forensic SciInt, 145:25-29

Ashmawy, M.M.; Nagy, A.A. and
Ibrahim, Z.A. (2004): Determination of sex from femur in Egyptians. Tanta Med. J., 32:100814

Bidmos, M.A. (2008): Estimation of stature using fragmentary femora in indigenous South Africans. Int. J. Leg. Med., 122 (4): 293-299.

Doshi, M.A. and Bhaskar, B.R. (2017): Sex determination from adult human femur by stepwise discriminant function analysis. International Journal of Current Medical and Pharm. Res., 3 (8):2140-2142.

Gomaa, M.S.; Hussein, W.F. and Abo Elezz, M.O. (2007): Sex determination from paranasal sinuses among Egyptians: computerized tomography study. Ain Shams J. Forensic Med. and Clin.Tox., IX: 176-91.

Khanal, L.; Shah, S. and Koirala, S. (2017a): Exploration of the coefficients of correlation of different segmental measurements with total length of disarticulated femoral bones: a systematic review. J. Morphol. Sci., 34 (2): 114-122.

Khanal, L.; Shah, S. and Koirala S. (2017b): Estimation of Total Length of Femur from its Proximal and Distal Segmental Measurements of Disarticulated Femur Bones of Nepalese Population using Regression Equation Method. J. Clin. Diag. Res., 11(3): HC01-HC05.

Kranioti, E.; Vorniotakis, N.; Galiatsou, C.; Iscan, M. and Michalodimitrakis, M. (2009): Sex identification and software development using digital femoral head radiographs. Forensic Sci Int, 189(1): 113: e1-7.

Lee, J.H.; Kim, Y.S.; Jeong, Y.G.; Lee, N.S.; Han, S.Y.; Tubbs, R.S. 
and Han, S.H. (2014): Sex determination from partial segments and maximum femur lengths in Koreans using computed tomography. Folia Morphol., 73 (3): 353-358.

Mall, G.; Graw, M.; Gehring, K.D. and Hubic, $M$. (2000):Determinationof sex from femora. Forensic Sci. Int., 113: 315-321.

Melamed, N.; Meizner, I.; Mashiach, R.; Wizitzer, A.; Glezerman, M. and Yogev, Y. (2013):Fetal sex and intrauterine growth patterns. J. Ultras. Med., 32 (1): 35-43.

Monisha, K. and Karpagam, $K$. (2016): Study of determination of sex from femur bone. Int. J. Advanc. Res., 4 (6): 1182-1183.

Mostafa, E.M.; El-Elemi, A.H.; ElBeblawy, M.A. and Dawood, A.A. (2012):Adult sex identification using digital radiographs of the proximal epiphysis of the femur at Suez Canal University Hospital in Ismailia, Egypt. Egyptian J. Forensic Sci., 2: 81-88.

Mukhopadhyay, P.P.; Ghosh, T.K. and Dan, U. (2010): Correlation between maximum femoral length and epicondylar breadth and its application in stature estimation: a population specific study in Indian Bengali males. J.IndianAcad. Forensic Med., 32 (3): 971-974.

Pandey, R. and Gaikwad, H. (2016): Sex determination by discriminant function analysis of femoral heads of a North Indian population.Indian J. Forensic Commun. Med., 3(3):172-175

Purkait, R. (2005): Triangle identified at the proximal end of femur: A new sex determinant. Forensic Sci. Int., 147(2):135-9.

Purkait, R. and Chandra, H. (2004): A study of sexual variation in Indian femur. Forensic Sci. Int., 146: 25-33.

Singh, A. (2017): Gender identification using discriminant function analysis of study population. J. Advanc. Med. Dent. Sci. Res., 5 (2): 16-18.

Solan, S. and Kulkarni, R. (2013): Estimation of total Length of Femur From Its Fragments in South Indian Population. J. Clin. Diagn. Res., 7 (10): 2111-2115.

Soni, G.; Dhall, U. and Chhabra, S. (2010): Determination of sex from femur: discriminant analysis. J. Anat. Soci. India, 59 (2): 216-221. 


\section{تحديد الجنس بقياس النهاية البعيدة للعظمة الفخذية للبالغين في محافظة}

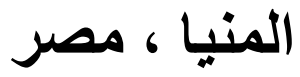

ليلعب تحديد الجنس من بقايا الهيكل العظمي البشري دور اً مهماً في تحديد الهوية، كما أن عظم الفخذ هو عظم مهم يستخدم لتحديد الجنس. لذا الهدف من هذه الدر اسة هو تمبيز الجنس للمصريين عن طريق قياسات للنهايات البعيدة لعظمة الفخذ.

وقد تم اختيار 96 عظمة فخذ جافة مكتملة التعظم من كلا الجنسين (45 يمين و 51 يسار ) لاجر اء خمسة إناء

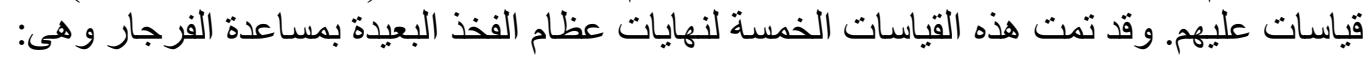

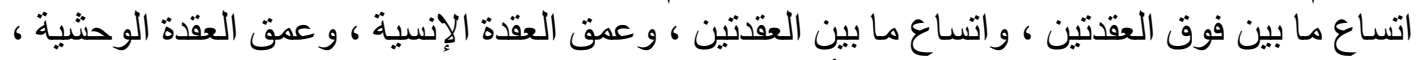

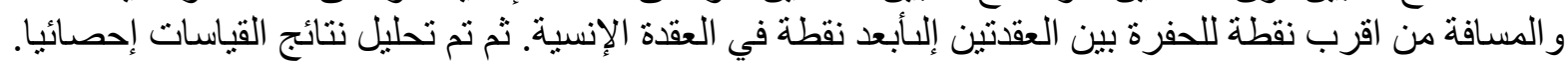

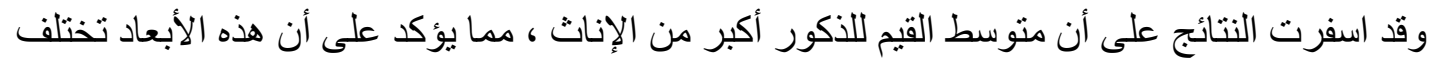

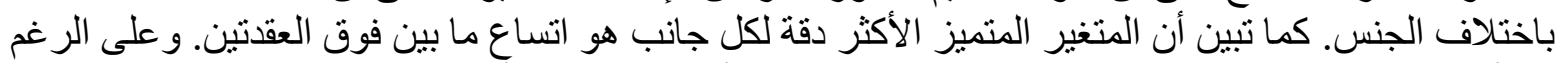

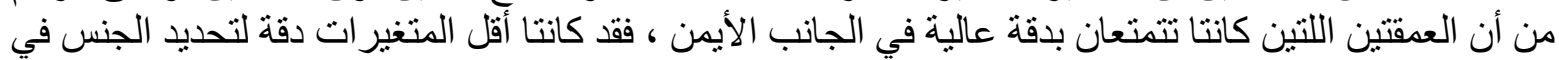

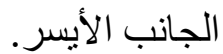

كما تم الحصول على أفضل دقة (93.3 ٪ ، 94.1 \%) للجانب الأيمن والأيسر على التو الي من خلال إجر اء تحليل متعدد التمييز للأبعاد الخمسة.

نستخلص مما سبق أن هذا البحث يسلط الضو ع على على أهمية نهايات عظام الفخذ البعيدة لتقييم الجنس في الرفات البشرية وخاصة في حالات العثور على عظام فخذ غير مكتملة. 